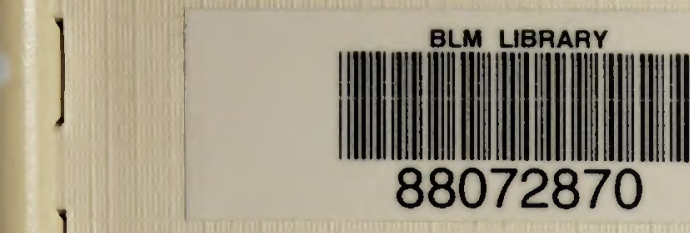

SPECIAL STATUS PLANT STRATEGY PLAN FOR THE LAS VEGAS DISTRICT

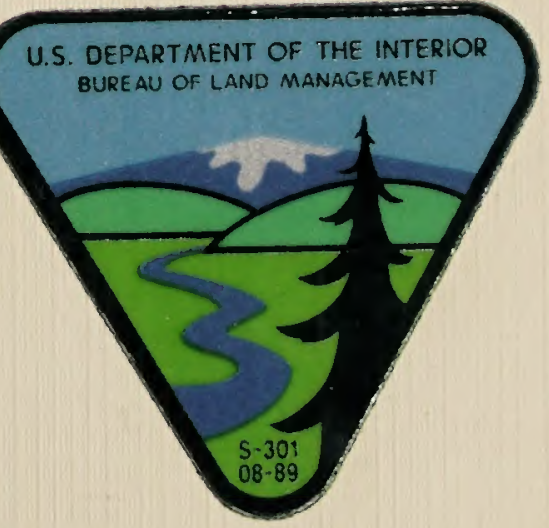




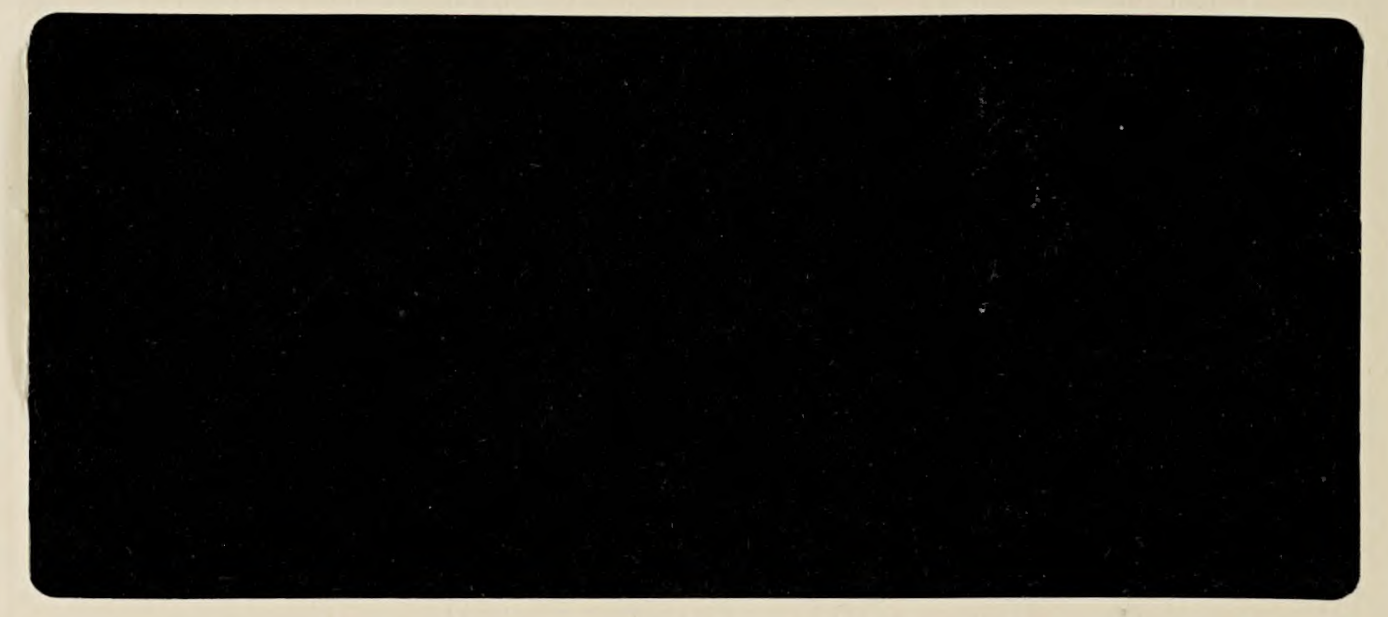




\title{
SPECIAL STATUS PLANT \\ STRATEGY PLAN \\ FOR THE LAS VEGAS DISTRICT
}

\author{
Prepared by \\ Bureau of Land Management \\ Las Vegas District Office
}

October 1992

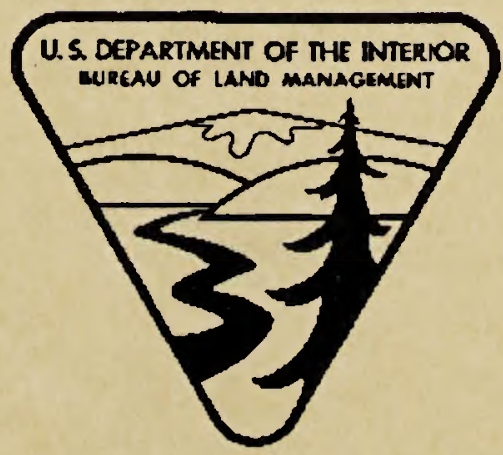




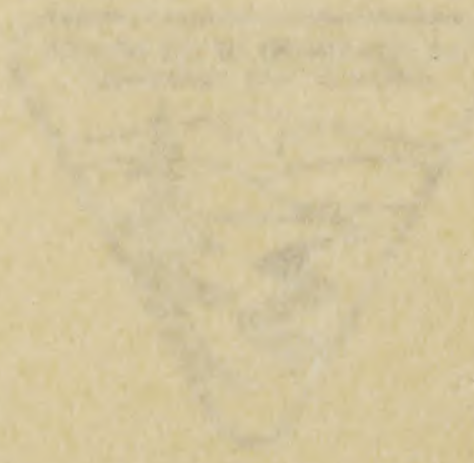




\section{Table of Contents}

1 INTRODUCTION AND BACKGROUND . . . . . . . . . . . . . 1

1.1 Purpose and Need . . . . . . . . . . . . . . 1

1.2 Study Area . . . . . . . . . . . . . . . . . 1

1.3 SSP in the Las Vegas District.......... . 3

2 STRATEGY PLAN . . . . . . . . . . . . . . . 3

2.1 Land-use Planning for Resource Protection..... 3

2.1.1 Stateline RA . . . . . . . . . . . . 6

2.1.1.1 Long-term Planning: Draft Stateline

RMP . • . . . . . . . . . 6

2.1.1.2 Activity Plans ......... . 9

2.1 .2 Caliente RA . . . . . . . . . . . 13

2.1.2.1 Long-term Planning . . . . . . 13

2.1.2.2 Activity Plans . . . . . . . . 13

2.2 Inventory and Studies.............. 14

2.2 .1 Inventory . . . . . . . . . . . . . 14

2.2.2 SSP Identification and Training Aids . . . 16

2.2.3 BLM Plant Database............ 17

2.2 .4 Studies . . . . . . . . . . . . 17

2.3 Monitoring . . . . . . . . . . . . . . 18

2.4 Coordination . . . . . . . . . . . . 18

3 CONCLUSIONS . . . . . . . . . . . . . . . 20

4 REFERENCES . . . . . . . . . . . . . . 20

APPENDIX 1. Sample of Nevada Natural Heritage form. . . . 21

BLM Library
Denver Federal Center
Bldg. 50, OC-521
P.O. BOX 25047
Denver, CO 80225 



\subsection{Purpose and Need}

The purpose of this document is to provide a framework for the conservation and management of special status plants (SSP) that will guide botanical activities for the Las Vegas District of the Bureau of Land Management (BLM). Special Status Plants are defined as those taxa which are listed 1) Federally as threatened or endangered ( $T \& E$ ) or as candidate $T \& E$ taxa, 2) by state, 3) by the BLM state Director as sensitive, or 4) due to restricted habitat or limited numbers based on available knowledge and which could become endangered in the future. The policy of the BLM mandates that SSP and their critical habitat be conserved and that their continued existence be assured. This plan delineates the objectives and strategies to understand, maintain, and improve rare plant resources, and to encourage cooperation between agencies and the public to achieve the common goal of making federal listing of SSP unnecessary.

In southern Nevada, multiple-use activities, rapid urban expansion, and introduction of aggressive non-native plant and animal species have increased habitat destruction of natural communities through competition for resources. Rare plants which already have restricted habitats are the most sensitive to such pressures. Progress to increase knowledge of rare plants in Nevada has been made by The Nature Conservancy (TNC), The Nevada State Museum, The Nevada Natural Heritage Program (NNHP), the Northern Nevada Native Plant Society (NNNPS), and academic institutions. All plant collection data have been compiled in the NNHP database and provided to BLM as a part of a cost-share program between NNHP and BLM. Through rare plant workshops, candidate plant species lists are regularly evaluated and updated. A great amount of rare plant information has been disseminated this way. But because of time and financial constraints, a vast amount of the Las Vegas District remains unsurveyed for SSP. A unified strategy plan will allow the BLM to better assess the status and response of rare and candidate plant populations to increasing pressures. Consolidating information, both already available and from future inventories, into a centralized BLM database will improve BLM's ability to determine land-use impacts and will provide a sound foundation on which to base land management decisions.

\subsection{Study Area}

The Las Vegas District of BLM occupies the extreme southern portion of Nevada and is comprised of approximately 7.1 million acres. Two Resource Areas (RA) make up the Las Vegas District: Stateline and Caliente (Figure 1). Stateline RA contains approximately 3.7 million acres of public land, with clark county accounting for most of the area but also including the southernmost portion of Nye County. Clark County, Nevada's most densely populated county, contains over two-thirds of Nevada's population, and is experiencing rapid expansion (BLM, 1992a). Ninety percent of Clark 



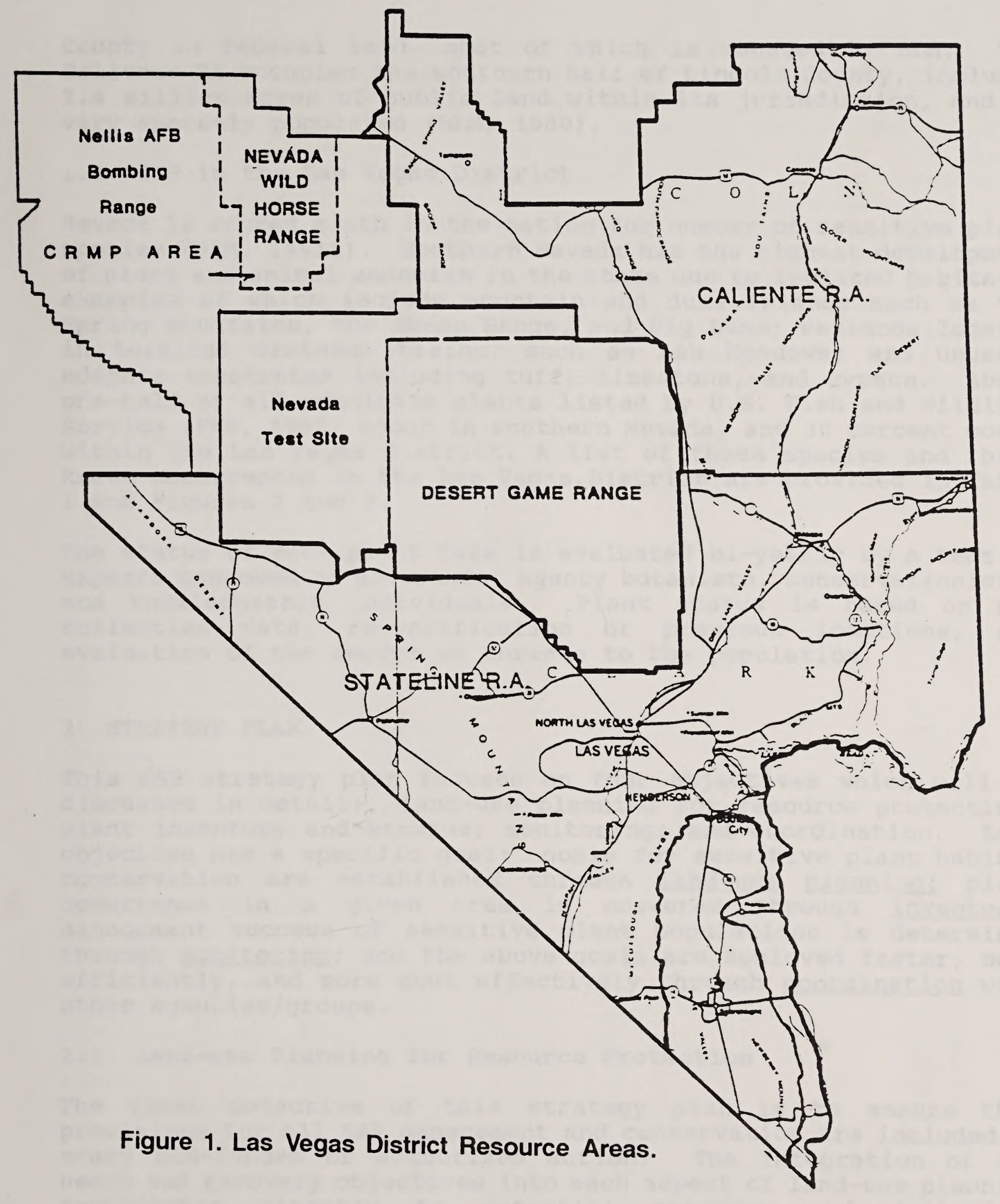



County is federal land, most of which is managed by BLM. The Caliente RA occupies the southern half of Lincoln county, includes 3.4 million acres of public land within its jurisdiction, and is very sparsely populated (BLM, 1980).

\subsection{SSP in the Las Vegas District}

Nevada is ranked sixth in the nation for number of sensitive plant species (BLM, 1991a). Southern Nevada has the highest development of plant and animal endemism in the state due to isolated habitats, examples of which include mountain and dune islands such as the Spring Mountains, the Sheep Range, and Big Dune; wetlands located in terminal drainage basins, such as Ash Meadows; and unusual edaphic substrates including tuff, limestone, and gypsum. About one-half of all candidate plants listed by U.S. Fish and Wildlife Service (FWS, 1992) occur in southern Nevada, and 30 percent occur within the Las Vegas District. A list of these species and their known occurrences in the Las Vegas District are provided in Table 1 and Figures 2 and 3 .

The status of each plant taxa is evaluated bi-yearly by a team of experts composed of government agency botanists, conservationists, and knowledgeable individuals. Plant status is based on new collection data, re-verification of previous locations, and evaluation of the degree of threats to the population.

\section{STRATEGY PLAN}

This SSP strategy plan focuses on four objectives which will be discussed in detail: land-use planning for resource protection; plant inventory and studies; monitoring; and coordination. Each objective has a specific goal: goals for sensitive plant habitat conservation are established through land-use planningi plant occurrence in a given area is answered through inventory; management success of sensitive plant populations is determined through monitoring; and the above goals are achieved faster, more efficiently, and more cost effectively through coordination with other agencies/groups.

\subsection{Land-use Planning for Resource Protection}

The first objective of this strategy plan is to ensure that provisions for all SSP management and conservation are included in every BLM-funded or authorized action. The integration of SSP needs and recovery objectives into each aspect of land-use planning contributes directly to potential recovery and delisting. Protection of sensitive plant resources is established in: longterm planning documents which forecast land-use needs, determine goals, and provide a framework for habitat conservation; and siteor species-specific management plans which would also include mitigation plans. These are described in detail below. 

Table 1. Special status plants in the Las Vegas District as of 1992. Resource Areas are designated as "S" - Stateline and "C" Caliente; counties are denoted as follows: "Cl" - Clark; "L" Lincoln; and "N" - Nye counties. Federal status nomenclature follows Federal Register (55FR 6184, 21 Feb., 1990) for listed plant taxa: "LE" - listed endangered; "LT" - listed threatened; Federal candidate taxa are "C1" - candidate endangered; "C2" candidate threatened; "C3" - no longer considered for $\mathrm{Cl}$ or $\mathrm{C2}$ listing, but still on NNNPS watch list. state plant status nomenclature is denoted by "CE" - endangered and "CY" - protected under NRS 527.060-.120. NNNPS status is as follows: "T" threatened, "E" - endangered, "W" - Watch list, "PE" - possibly extinct, and "D" - deleted from NNNPS list. Plants rare due to limited numbers are noted by a " $\checkmark$ ". Possible but not confirmed occurrence is denoted by "(?)".

species

RA

County

status

Fed./state/NNNPS

\section{Listed species}

Astragalus phoenix

Centaurium namophilum

Encelopsis nudicaulis var. corrugata

Grindelia fraxino-pratensis

Ivesia kingii var. eremica

Mentzelia leucophylla

Nitrophila mohavensis

Spiranthes diluvialis

$\begin{array}{lll}S & N & L T, C E, T \\ S & N & L T, C E, T \\ S & N & L T, C E, T \\ S & N & L T, C E, T \\ S & N & L T, C E, T \\ S & N & L T, C E, T \\ S & N & L E, C E, E \\ C & L & L T, C E, T\end{array}$

\section{Candidate species}

Angelica scabrida

Arctomecon californicum

A. merriami

Arenaria kingii ssp. rosea

Asclepias eastwoodiana

Astragalus aequalis

Astragalus eurylobus

A. mohavensi var. hemigyrum

A. oophorus var. clokeyanus

A. oophorus var. lonchocalyx

A. remotus

A. triquetrus (=A. geyeri var. triquetrus)

Calochortus striatus

Cordylanthus tecopensis

chrysothamnus eremobius

$\begin{array}{lll}\mathrm{S} & \mathrm{Cl} & \mathrm{C} 2, \mathrm{~T} \\ \mathrm{~S} & \mathrm{Cl} & \mathrm{C} 2, \mathrm{CE}, \mathrm{T} \\ \mathrm{S} & \mathrm{Cl}, \mathrm{N} & \mathrm{C} 2, \mathrm{~W} \\ \mathrm{~S} & \mathrm{Cl} & \mathrm{C} 2, \mathrm{~T} \\ \mathrm{C} & \mathrm{L} & \mathrm{C} 2, \mathrm{~W} \\ \mathrm{~S} & \mathrm{~N} & \mathrm{C} 2, \mathrm{~T} \\ \mathrm{C} & \mathrm{L} & \mathrm{C} 2, \mathrm{~W} \\ \mathrm{~S} & \mathrm{Cl} & \mathrm{C} 2, \mathrm{CE}, \mathrm{E} \\ \mathrm{S} & \mathrm{Cl} & \mathrm{C} 1 \\ \mathrm{C} & \mathrm{L} & \mathrm{C} 2, \mathrm{~W} \\ \mathrm{~S} & \mathrm{Cl} & \mathrm{C} 2, \mathrm{~W} \\ & & \mathrm{C} 2, \mathrm{CE}, \mathrm{T} \\ \mathrm{S} & \mathrm{Cl} & \mathrm{C} 2, \mathrm{~W} \\ \mathrm{~S} & \mathrm{Cl}, \mathrm{N} & \mathrm{C} 2, \mathrm{~T} \\ \mathrm{~S} & \mathrm{~N} & \mathrm{C} 2, \mathrm{~W} \\ \mathrm{~S}, \mathrm{C} & \mathrm{Cl}, \mathrm{L} & \end{array}$





\section{Candidate plants}

Cryptantha hoffmanii

c. insolita

Cymopterus ripleyi var. saniculoides

Epilobium nevadense

Erigeron ovinus

Eriogonum bifurcatum

E. viscidulum

Forsellesia clokeyi (=Glossipetalon)

F. pungens var. glabra (=Glossipetalon)

opuntia whipplei var. multigeniculata

Penstemon albomarginatus

P. bicolor ssp. bicolor

P. bicolor ssp. roseus

P. fruticiformis ssp. amargosae

Salvia dorrii var. clokeyi Sclerocactus schleseri Selaginella utahensis spiranthes infernalis

\section{Sensitive Plants}

Anulocaulis leiosolinus Arenaria stemomeres Astragalus ackermanii A. calycosus var. monophyllidius

A. gilmanii

A. minthorniae

Var. minthorniae

A. mokiacensis

Brickellia knappiana

Castilleja martinii

var. clokeyi

Coryphantha vivipara var. rosea

Dudleya pulverulenta ssp. arizonica

Cyptantha tumulosa

E. heermanni var. clokeyi

Ferocactus acanthodes var. lecontei

Haplopappus compactus

\section{RA}

$S(?)$

County

$\mathrm{S}$

C(?)

$\mathrm{C}$

$\mathrm{S}, \mathrm{C}$

$\mathrm{S}$

$\mathrm{S}$

$S(?)$
$S$

$\mathrm{N}$

$\mathrm{Cl}$

C2

$\mathrm{C} 2, \mathrm{CE}, \mathrm{PE}$

$\mathrm{C} 2$, in

$\mathrm{C} 2$, w

$\mathrm{C} 2$, w

$\mathrm{C} 2, \mathrm{~W}$

$C 2, C E, T$

$\mathrm{C} 2, \mathrm{w}$

$\mathrm{C} 2, \mathrm{~W}$

Cl

$\mathrm{C} 1, \mathrm{CE}, \mathrm{T}$

$\mathrm{C} 2, \mathrm{~T}$

$\mathrm{C} 2$, w

C2, D

$\mathrm{C} 2, \mathrm{~T}$

$\mathrm{C} 2$, W

$\mathrm{C} 2, \mathrm{CY}, \mathrm{W}$

$\mathrm{C} 2, \mathrm{~W}$

$\mathrm{C} 2, \mathrm{~T}$

\begin{tabular}{|c|c|c|}
\hline S & $\mathrm{Cl}$ & v \\
\hline C & L & $3 C, W$ \\
\hline$S, C$ & $\mathrm{Cl}, \mathrm{L}$ & $3 \mathrm{C}, \mathrm{W}$ \\
\hline $\begin{array}{l}S, C \\
C(?)\end{array}$ & $\begin{array}{l}\mathrm{Cl}, \mathrm{L}, \mathrm{N} \\
\mathrm{L}\end{array}$ & $\begin{array}{l}3 C, W \\
v, W\end{array}$ \\
\hline$S, C$ & $\mathrm{Cl}, \mathrm{L}, \mathrm{N}$ & 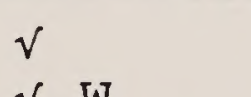 \\
\hline$S$ & $\mathrm{Cl}$ & $v, w$ \\
\hline $\mathrm{S}$ & $\mathrm{Cl}$ & $3 c, w$ \\
\hline $\mathrm{s}$ & $\mathrm{Cl}$ & $v$ \\
\hline$S, C$ & $\mathrm{Cl}, \mathrm{L}, \mathrm{N}$ & $3 C, C Y, D$ \\
\hline $\mathrm{s}$ & $\mathrm{Cl}$ & $\checkmark$ \\
\hline $\mathrm{S}$ & $\mathrm{Cl}, \mathrm{N}$ & $3 \mathrm{C}, \mathrm{W}$ \\
\hline$S$ & $\mathrm{Cl}, \mathrm{N}$ & $v, W$ \\
\hline $\begin{array}{l}S, C \\
S\end{array}$ & $\begin{array}{l}\mathrm{Cl}, \mathrm{N}, \mathrm{L} \\
\mathrm{Cl}\end{array}$ & $\begin{array}{l}3 C, C Y, W \\
V\end{array}$ \\
\hline
\end{tabular}



Table 1 (cont.)

\section{Sensitive plants}

Penstemon petiolatus

P. thompsoniae

sp. jaegeri

Perityle megalocephala

var. intricata

Petalonyx parreyi

Phacelia palmeri

Polygala subspinosa

var. heterorhyncha

Porophyllum pygmaeum

Sclerocactus polyancistrus

Tiquilia latior
$\mathrm{RA}$

S, C

county

status

$S$

$S$

$S$

$S$

$C(?)$

$\mathrm{S}$

$S$

$\mathrm{S}$
$\mathrm{Cl}, \mathrm{L}, \mathrm{N}$

$\mathrm{Cl}$

$\mathrm{Cl}, \mathrm{N}$

$\mathrm{Cl}$

Cl

$\mathrm{L}$

$\mathrm{Cl}$

$\mathrm{N}$

Cl $\checkmark$

$3 \mathrm{C}, \mathrm{W}$

$3 \mathrm{C}, \mathrm{W}$

$\checkmark$

$\checkmark$

$3 C, W$

$\checkmark$

$3 C, C Y, D$

Land-use planning can be far-reaching and long-term, projecting land uses ten or more years and providing a framework to balance multiple-use practices with conservation of resources. The major land uses in the Las Vegas District are mining, ranching, offhighway vehicle (OHV) recreation, and urban expansion. Examples of long-term management plans include a Resource Management Plan (RMP) and/or a Management Framework Plan (MFP). These types of BLM "Master Plans" are directed by each Resource Area. In each RMP/MFP, resource protection for SSP can be accomplished through land acquisitions, special management area designations which can restrict or forbid various types of activities determined to be detrimental to SSP populations, and termination of domestic or feral animal grazing in sensitive areas. Within the framework of the RMP/MFP, species specific activity plans can be designed, such as Habitat Management Plans (HMP) and Recreation Area Management Plans (RAMP). For the Las Vegas District, summaries of the Draft stateline RMP and Caliente MFP as they pertain to SSP conservation follow.

\subsubsection{Stateline RA}

\subsubsection{Long-term Planning: Draft Stateline RMP}

Land use planning and conservation alternatives are addressed in the Draft Stateline RMP (1992a). Most of the proposed special management areas are for the recovery of the threatened desert tortoise, a brief history of which follows.

Due to the potential economic impacts (i.e. urban development and expansion) to Las Vegas, Nevada as a result of the Federal listing of the desert tortoise, clark county and the cities of Las Vegas, 



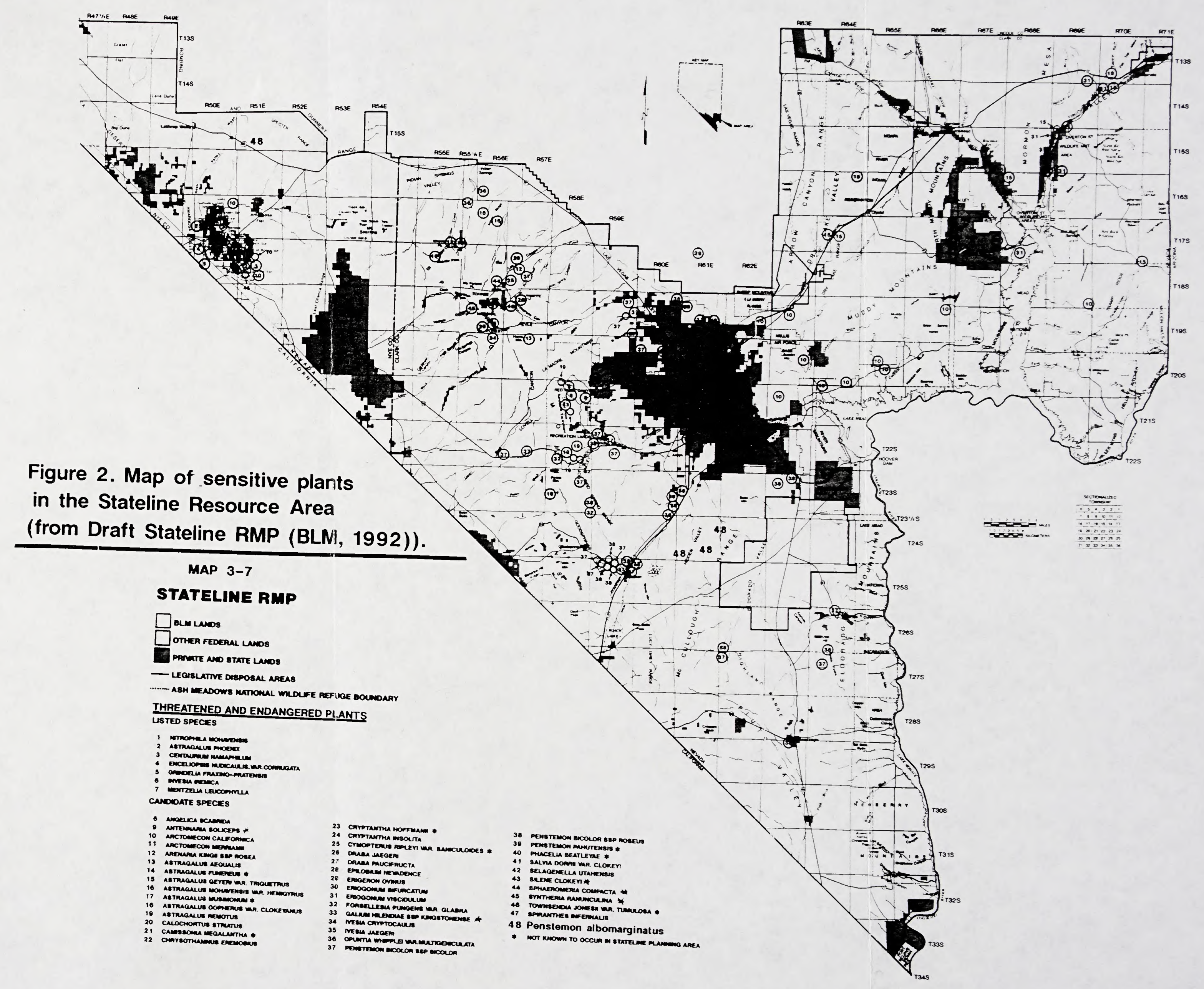





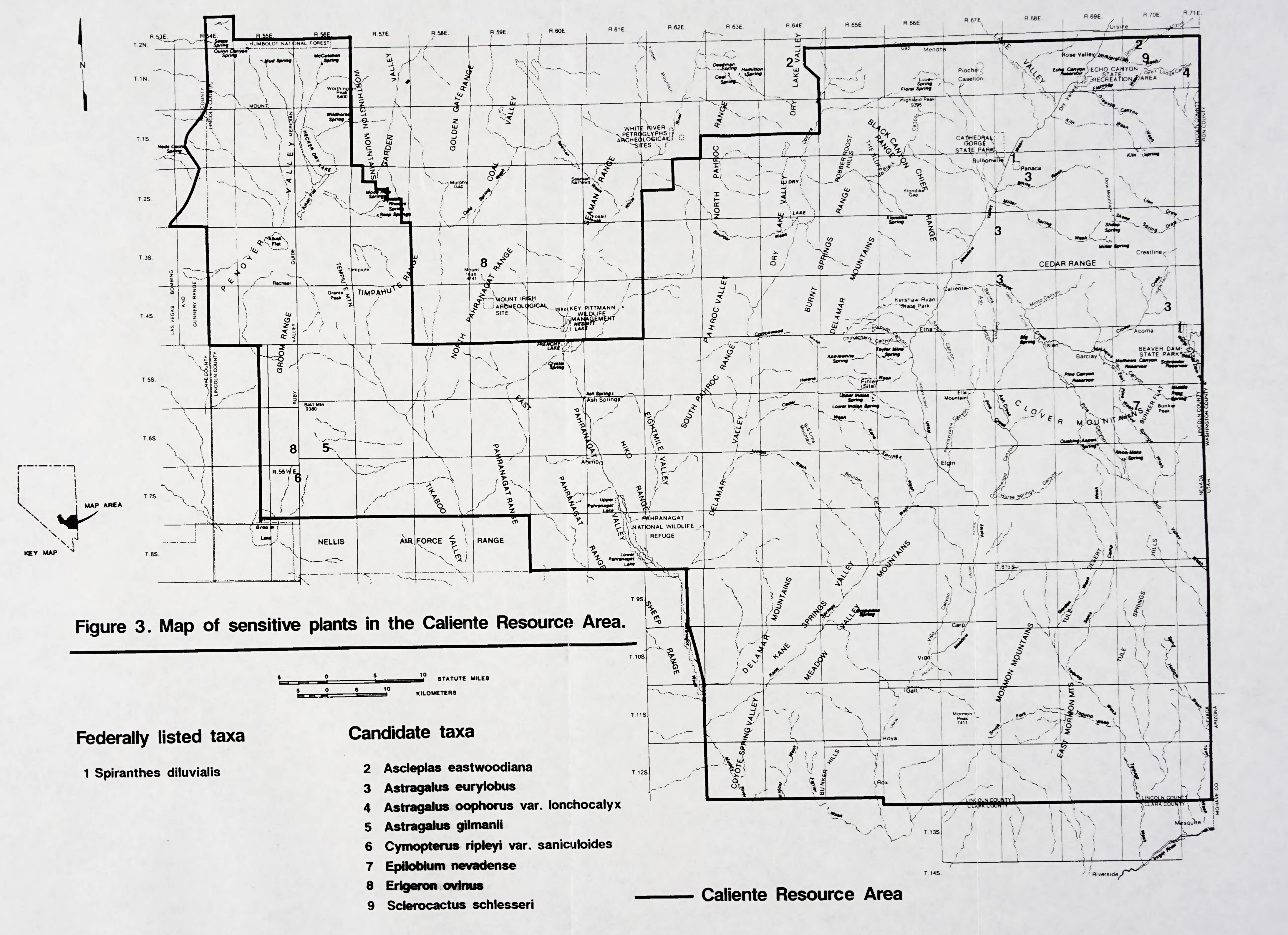



North Las Vegas, Henderson, and Boulder City developed the ShortTerm Desert Tortoise Habitat Conservation Plan. This plan provides for "take" (i.e. removal) of tortoises within Las Vegas Valley while cooperatively establishing conservation areas for the desert tortoise on public lands managed by the BLM and National Park Service (NPS). Under the plan, approximately 400,000 acres of tortoise habitat are to be managed primarily for the desert tortoise through the establishment of Tortoise Management Areas (TMA). This plan will ultimately be replaced within three years by a long-term plan which will identify additional TMAs. concurrently, the stateline RMP has incorporated land-use alternatives that may be proposed in any long-term HCP developed by Clark county. The U.S. Fish and Wildlife Service is now developing a recovery plan for the desert tortoise which will identify areas to be managed primarily for viable tortoise populations. These concurrent processes will eventually culminate in a BLM land-use plan decision through the clark County Resource Management Plan that will in all probability establish Areas of critical Environmental Concern (ACEC) for the protection of desert tortoise habitat with the goal of meeting recovery requirements for the desert tortoise.

The establishment of these ACECs will also provide considerable benefit to SSP. Therefore, a major emphasis will be to document the occurrence, distribution, and density of SSP within the ACECS to determine if they provide adequate protection and benefit to particular species, especially in terms of viable populations. Additional actions may be taken outside ACECs, if necessary, to ensure that special status species are afforded adequate protection for long-term viability. These actions together should reduce the need or likelihood of Federally listing such species in the future.

Because the RMP is currently in draft form, predicting the extent to which ACECs will be created and therefore the extent of their benefit to SSP is impossible at this time. In any case, the Stateline RMP, once approved, will be the guiding force behind SSP species management within the Las Vegas District. Examples of proposed ACECS for BLM's "Preferred Alternative" are presented in Figure 4 and Table 2. The definitions of ACECS and other BLM land conservation designations are presented in Table 3.

\subsubsection{Activity Plans}

Many types of activity plans exist and SSP issues must be incorporated into each one. Besides an HMP for Ash Meadow (BLM, 1980a), other activity plans to this date have not adequately addressed SSP plants.

The following projects concerning SSP in the stateline Resource Area will be pursued. Three separate HMPs will be developed for the Blue Diamond cholla, Geyer milk-vetch, and the California bear 



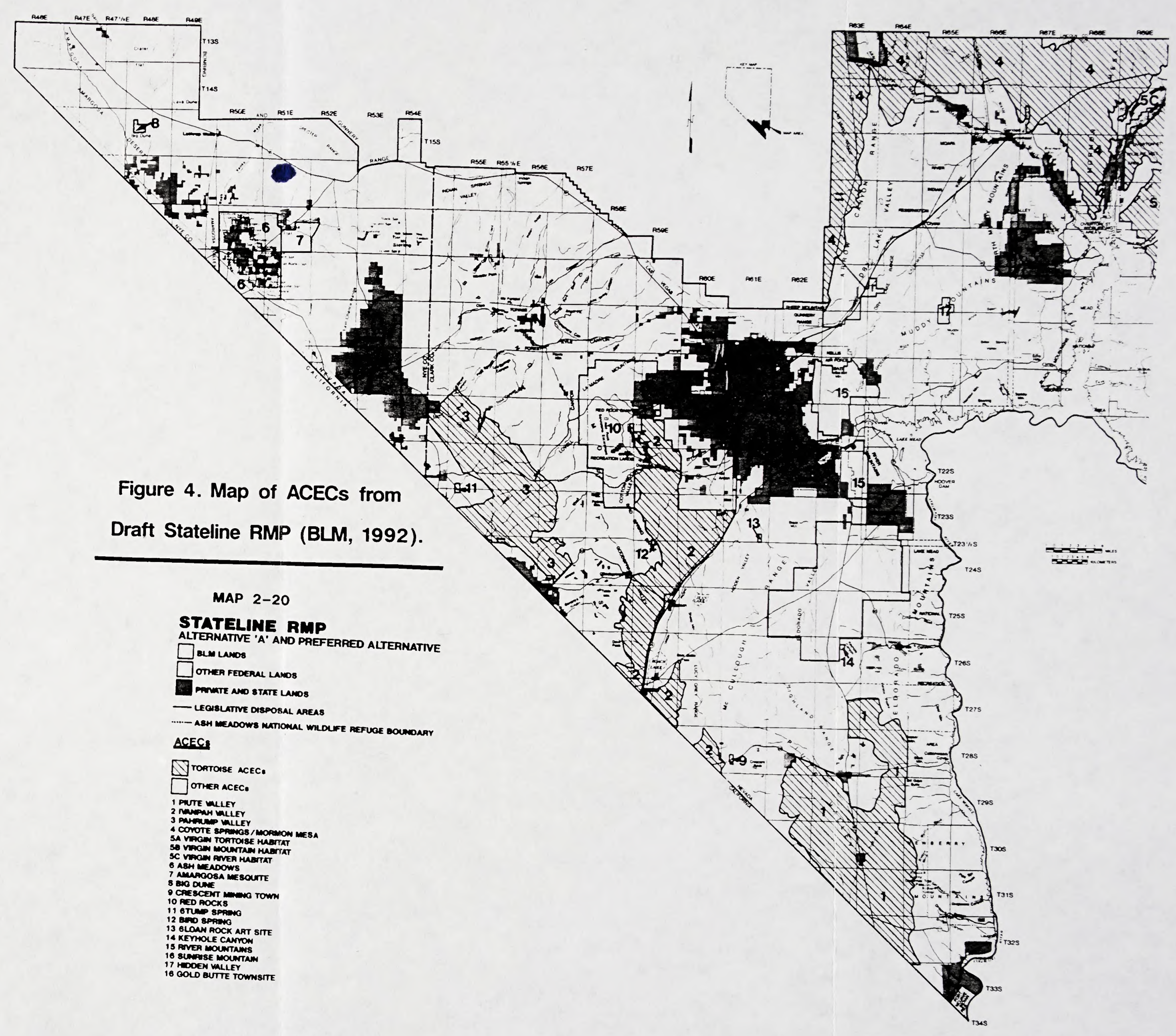



Table 2. List of proposed Areas of Critical Environmental Concern (ACEC) compiled from Alternative D (BLM preferred Alternative), Draft stateline Resource Management Plan (BLM, 1992a).

\begin{tabular}{|c|c|c|}
\hline Name & $\begin{array}{l}\text { Area } \\
\text { (acres) }\end{array}$ & Principal Value \\
\hline Piute Valley ACEC & 189,000 & $\begin{array}{l}\text { tortoise, botanical } \\
\text { some cultural }\end{array}$ \\
\hline Ivanpah ACEC & 147,860 & tortoise, T\&E plants \\
\hline Pahrump Valley ACEC & 116,600 & tortoise \\
\hline $\begin{array}{l}\text { Coyote Spring } \\
\text { /Mormon Mesa ACEC }\end{array}$ & 299,300 & $\begin{array}{l}\text { tortoise, cultural, } \\
\text { paleontological }\end{array}$ \\
\hline Virgin ACEC & 216,500 & $\begin{array}{l}\text { botanical, } \\
\text { tortoise, T\&E fish, } \\
\text { cultural, riparian }\end{array}$ \\
\hline Ash Meadows ACEC & 37,078 & $\begin{array}{l}\text { T\&E plants, } \\
\text { invertebrates, fish }\end{array}$ \\
\hline Big Dune ACEC & 1,000 & $\mathrm{~T} \& \mathrm{E}$ invertebrates \\
\hline River Mountains ACEC & 14,600 & $\begin{array}{l}\text { bighorn sheep, } \\
\text { scenic }\end{array}$ \\
\hline Amargosa Mesquite ACEC & 9,600 & botanical, wildlife \\
\hline Hidden Valley ACEC & 3,360 & cultural \\
\hline Sloan Rock Art site ACEC & 320 & cultural \\
\hline $\begin{array}{l}\text { Crescent Mining Townsite } \\
\text { ACEC }\end{array}$ & 320 & cultural \\
\hline Red Rock Canyon ACEC & 83,100 & $\begin{array}{l}\text { cultural, scenic } \\
\text { botanical }\end{array}$ \\
\hline $\begin{array}{l}\text { Gold Butte Historic Mining } \\
\text { Townsite ACEC }\end{array}$ & 120 & cultural \\
\hline $\begin{array}{l}\text { Bird Spring Archaeological } \\
\text { Site ACEC }\end{array}$ & 160 & cultural \\
\hline Stump Spring ACEC & 560 & cultural \\
\hline Keyhole Canyon ACEC & 160 & cultural \\
\hline Sunrise Mountain ACEC & 31,400 & $\begin{array}{l}\text { botanical, } \\
\text { cultural, } \\
\text { geological }\end{array}$ \\
\hline & $\begin{array}{l}\text { tal acres } \\
1,151,038\end{array}$ & $\begin{array}{l}\text { Total acres for } \\
\text { botanic value } \\
=714,538\end{array}$ \\
\hline
\end{tabular}



Table 3. Glossary of land conservation designations (from BLM, $1991 \mathrm{~b}$.

Area of Critical Environmental Concern (ACEC). An area designated under the authority of the Federal Land Policy and Management Act of 1976 to protect natural resources, systems or processes that have more than local significance or have qualities or circumstances that makes them rare, irreplaceable, or vulnerable to adverse change.

Outstanding Natural Area. A designation intended to preserve the natural features of an area for the purpose of recreation. Current policy requires that ONAs also be designated as ACECs.

Research Natural Area (RNA). A designation imparted to an area to preserve its natural features for the purposes of research and education. Current policy requires that RNAs also be designated as ACECS.

Special Management Areas (SMA). An area requiring special management or focus. It may or may not meet the criteria of an ACEC.

claw poppy. Blue Diamond cholla (Opuntia whippleyi var. multigeniculata) is a Category I cactus with extremely limited distribution and threatened habitat (gypsum mining operations). Geyer milk-vetch (Astragalus triquetrus) is a Category 2 annual limited to the Moapa and Virgin River drainages. The California bearclaw poppy (Arctomecon californicum) is a southern Nevada endemic which thrives on gypsum outcrops, and though once fairly abundant, its populations have been declining at an alarming rate by gypsum mining, urban expansion, and OHV activity. Attempts to propagate and transplant this species have so far failed.

Several plant taxa have been rarely collected and should be carefully inventoried and monitored: half-ring pod milk-vetch (Astragalus mohavensis var. hemigyrus), Clokey milk-vetch (Astragalus aequalis), and Lee Canyon milk-vetch (Astragalus oophorus var. clokeyanus). These three species occur in the northern foothills of the Spring Mountains. Other taxa such as white-margined beardtongue (Penstemon albomarginatus) are limited in distribution but have been collected over time in reliable locations. Such taxa need to be further inventoried while monitoring and preserving their present habitat.

Resource protection is paramount when considering the impacts from BLM-authorized projects including powerline and pipeline construction, large-scale mining operations, grazing allotments, 

and commercial OHV races. A commitment must be made in both Resource Areas to mollify the adverse consequences from such activities through mitigation plans. For a given activity, mitigation plan may require sensitive plant avoidance, transplanting, seed collection, and propagation. Additionally, it can entail a complete or partial revegetation of the affected area(s) or fencing-off sensitive areas from further disturbance.

\subsubsection{Caliente RA}

\subsubsection{Long-term Planning: The Caliente MFP}

The Caliente MFP, prepared in 1980 (BLM, 1980b), reflects more traditional land-use management options such as ranching, mining, and OHV use. Areas under some kind of protection in the MFP total about 29,000 acres and are presented in Table 4. Almost ninety percent of the area under special management classification was valued for unique botanical resources, yet the total area represents less than 1 percent of the Caliente RA. Since Caliente $\mathrm{RA}$ has at least nine candidate plant taxa occurring (or 22 percent of the candidate plant species for the Las Vegas District) and at least eight other sensitive plant taxa, clearly updating the MFP to include botanical resource management is needed.

The following are projects which will be pursued in the caliente RA. Several plant taxa in the caliente RA are poorly understood in terms of distribution. Efforts will be made to determine the distribution of Peck station milk-vetch (Astragalus eurylobus), Panamint milk-vetch (Astragalus gilmanii), and long-calyx milkvetch (Astragalus oopherus var. Ionchocalyx).

\subsubsection{Activity Plans}

An ambitious study would be to intensively inventory the wetlands near Panaca for the Ute lady's-tresses (Spiranthes diluvialis), a Federally listed threatened orchid. If this orchid cannot be found, the possibility of re-introducing it into BLM-managed wetlands near Panaca should be investigated for feasibility. This orchid historically occurred in this area, the last known collection of which was made in 1936. Unfortunately, agricultural expansion has likely extirpated the population. Working with other agencies such as the FWS and TNC to identify and acquire appropriate critical habitat and to investigate propagation by cuttings and/or seed, a BLM recovery plan can be designed and implemented (see Section 2.4). 

Table 4. Special management areas in the Caliente Resource Area (compiled from Caliente MFP, 1980). Outstanding Natural Area is abbreviated ONA.

\begin{tabular}{||l|c|c||}
\hline \multicolumn{1}{|c|}{ Name of Area } & Area (acres) & Biological Value \\
\hline $\begin{array}{l}\text { Delamar Joshua Tree } \\
\text { Forest }\end{array}$ & 23,000 & botanic \\
\hline $\begin{array}{l}\text { East Mormon } \\
\text { Mountains Cactus } \\
\text { Area }\end{array}$ & 2,500 & botanic \\
\hline \begin{tabular}{l} 
Highland Peak (ONA) \\
\hline $\begin{array}{l}\text { Ash Spring } \\
\text { Mormon Peak Caves }\end{array}$
\end{tabular} & 480 & natural features \\
\hline $\begin{array}{l}\text { kangaroo rat } \\
\text { habitat }\end{array}$ & 1,500 & wetland \\
\hline $\begin{array}{l}\text { Quaking Aspen } \\
\text { Spring }\end{array}$ & 1,200 & wildife \\
\hline
\end{tabular}

Total acres $=28,745$

Total acres for

botanic value

$=25,525$

\subsection{Inventory and studies}

The development of an adequate information base on SSP is essential for land-use planning, and will be achieved by the following: conducting field inventories to determine the distribution and abundance of special status plants on BLM lands; developing a training aids to educate botanists and inventory personnel in identification of SSP; developing a centralized BLM plant database; and studying the ecological and environmental requirements for $\mathrm{T} \&$ E plant success.

\subsubsection{Inventory}

Basic inventory of lands for SSP is one of the Las Vegas District's most pressing needs. Although all BLM land unsurveyed for SSP needs attention, inventory priorities are for 1) proposed project sites, such as transmission line corridors and land disposal areas that may affect Federally listed or candidate plant species;

2) Special Recreation Management Areas as outlined in the Draft Stateline RMP, especially areas that may sustain heavy use from OHV and other activities; and 3) Federally listed $T$ \& E species that have historic or unconfirmed occurrence on BLM land (e.g. 


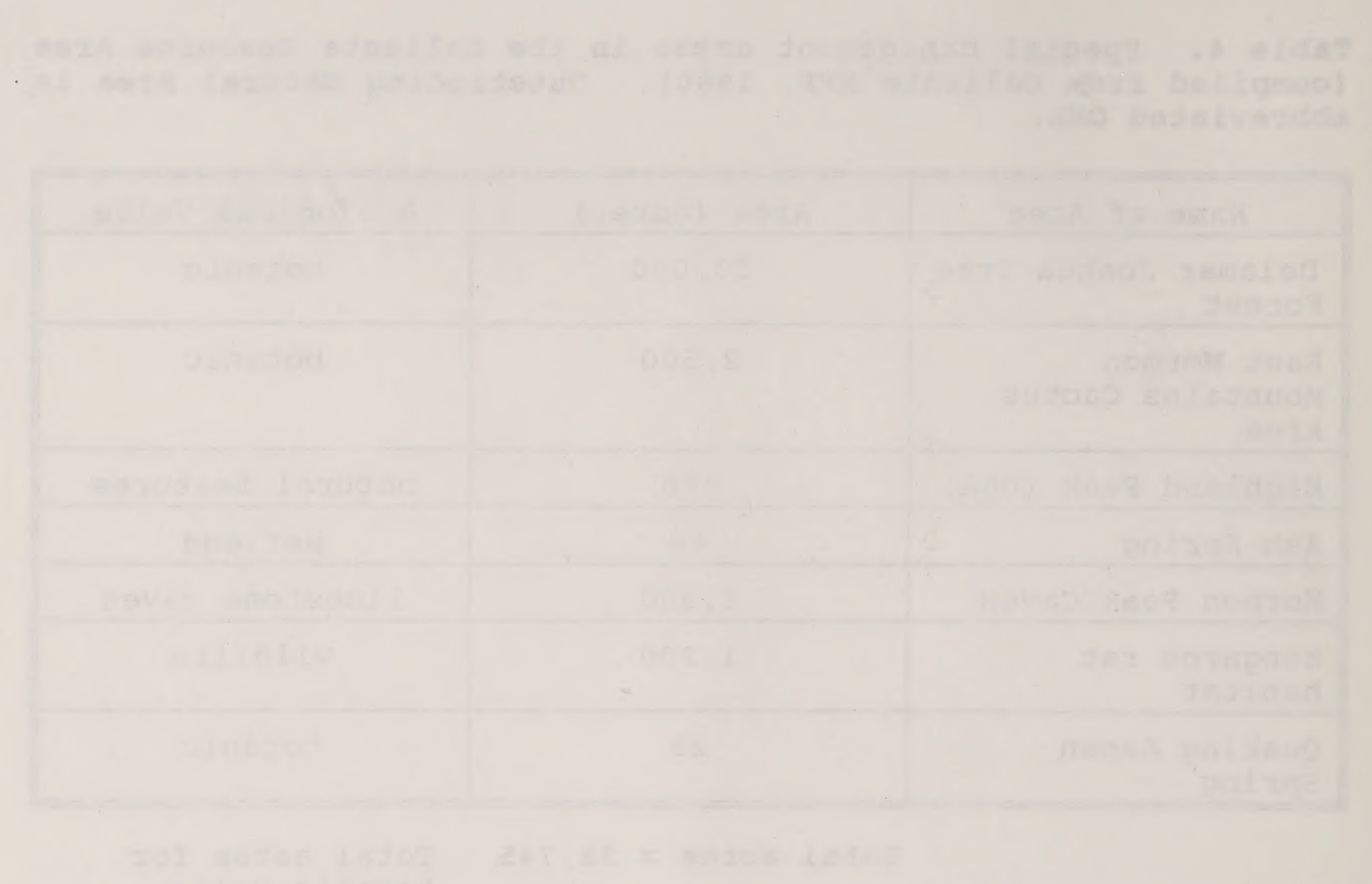


Spiranthes diluvialis in Lincoln county).

Field surveys for SSP are appropriate in determining the extent that a candidate plant will be affected by a proposed action or project when 1) based upon an initial environmental assessment the project may damage plant habitat; 2) candidate plants have historically been identified on the project site, but adequate information for impact assessment is lacking; or 3) no initial biological assessment has been conducted, and the occurrence of a candidate plant or its habitat is unknown.

Other lands to be focused upon for inventory are the ACECs as proposed in the Draft Stateline RMP (see Section 2.1.1). For example, the proposed Piute Valley Tortoise Management Area (TMA) in southern Clark county (Stateline RA) is also a part of a proposed ACEC in the Draft stateline RMP. This desert valley contains a very high density of desert tortoise. A sensitive plant inventory was conducted there in spring, 1992. Because this valley is the prototype of tortoise management areas, a complete flora and vegetation study should be performed to document the vascular plants and communities within the boundaries of this TMA. Other proposed TMAs will be inventoried for SSP occurrence.

Starting with known locations of target species, inventory personnel will work toward recognizing habitat types and edaphic requirements of taxa being surveyed. Field surveys must be conducted in a manner that will locate any SSP that may be present, using established field techniques and Geographic Position System (GPS) technology, if possible. The following are basic guidelines and recommendations for conducting plant inventories.

- Inventories should be conducted during the time of year when the target species are visible and identifiable (i.e. usually at flowering time), and should be performed for all SSP and plant communities.

- Inventories should include all Federal candidate, state listed, and sensitive species. The Nevada NNHP should be consulted to determine which plants should be included in the inventory.

Plant surveys should be performed using systematic field techniques to ensure a thorough coverage of target area. Use of GPS technology should be made so that plant locations can be automatically transferred into the BLM plant database. All species at each site surveyed should be documented, and any unknown plants collected and identified. This ensures that unexpected (or perhaps even 

new) candidate taxa are documented.

Collections should be made according to Federal and state permit regulations. Conservation ethics should be considered when collecting voucher specimens of very rare plants. Photography of target plant taxa and the habitat should be used with collection (or in lieu of collection if necessary) for plant documentation. Voucher specimens should be deposited in a recognized public herbarium for future reference.

- Field survey reports must include the following information: 1) project or area description, including a detailed map of the project location or study area; 2) a description of the biological setting referencing the community nomenclature used, and a vegetation map; 3 ) detailed description of survey methodology; 4) dates of field surveys; 5) results of survey, including detailed maps; 6) an assessment of potential impacts; 7) discussion of the importance of candidate plant populations with consideration of nearby populations and total species distribution; 8) recommended mitigation measures to reduce or avoid impacts; 9) list of all the species identified; 10) name of investigator(s); and 11$)$ references cited, persons contacted, herbaria visited, and disposition of voucher specimens.

- Information on SSP, including GPS data should be transferred to the BLM database.

- NNHP plant survey forms should be completed and sent to the NNHP botanist to keep current their database (see Appendix I).

\subsubsection{SSP Identification and Training Aids}

Sensitive plant handbooks have been successfully developed in other BLM offices (e.g. Schoolcraft, 1990) to aid inventory personnel in identification and documentation of sensitive plants on BLM project clearance areas. A similar handbook will be developed for the Las Vegas District. The handbook will be comprised of a list of plants (which can be updated bi-yearly in the form of addenda), status, plant descriptions, illustrations, vegetation community types in which they occur, habitat, elevation, and color photographs. The handbook will be available to field survey personnel in the RAs. To complement the handbook, a BLM herbarium is being developed that 

will focus on sensitive plants and similar-appearing plants for which they could be confused, and a photographic slide library showing the plant and its habitat. Ultimately, a sensitive plant identification workshop will be developed to aid biologists, range conservationists, and soil scientists in SSP identification. This training could be offered yearly or bi-yearly and would emphasize species identification and habitat recognition.

\subsubsection{BLM Plant Database}

To ensure maximum flexibility of data retrieval and broadest applicability of data use, the BLM plant database should interface with the District's Geographic Information System (GIS) and Land Information System (LIS) capabilities. An example of a compatible format is d-Base software. The rewards of doing this are the following.

- Plant inventory location data can stored
directly using GP technology and the
information down-loaded automatically.
Accuracy of plant location and ease of re-
location of populations for future monitoring
are increased.
Plant populations can be displayed either
graphically (maps) or alpha-numerically in
hardcopy form.
- Habitat planning and conflict resolution can
be made easier and more efficient through
over-laying of different elements on base
maps.

A database will be developed and implemented for the storage and retrieval of SSP information. This database will interface with the BLM's GIS and LIS capabilities. Consolidating available information from the NNHP database along with data from SSP inventories will provide a centralized source of botanical information which will be a very powerful tool in conservation and management of rare plant resources.

\section{2 .4 studies}

Studies enriching the understanding of the ecology and critical habitat requirements of SSP will help to better manage populations. Cooperative research with academic institutions to investigate these ecological questions should be undertaken whenever feasible because these facilities have the expertise, equipment, and support personnel to perform the necessary experiments. Studies can focus, for example, on pollination requirements, seed production, viability, and predation experiments, propagation studies, and plant-soil interactions. 



\subsection{Monitoring}

The third objective of this plan concerns the evaluation of population trends and habitat conditions through regular monitoring. Monitoring a population enables biologists to assess how well management prescriptions are working, whether and how they should be changed if necessary to promote progress, recovery, and long-term security of the taxon. Periodic evaluations over time aid in understanding the population biology of the plant. Rare plant monitoring standards, once developed, will be incorporated into HMPs and recovery plans developed by the stateline and Caliente RAs.

\subsection{Coordination}

The final objective in this plan deals with coordinating conservation activities between BLM, other agencies and groups, and the public to achieve the common goals of plant conservation and delisting. Agencies currently or potentially involved in BLM activities include Nevada Divisions of Wildlife and Forestry, the US Forest Service, FWS, National Park Service (NPS), US Airforce (Nellis Bombing Range), TNC, NNHP, Clark County, UNLV, native plant societies, and many "user" groups representing mining and ranching interests and OHV recreationists. The benefits of cooperation are many:

- Sharing information avoids duplication of effort which ultimately reduces the cost of a project.

- Plant species occurring across jurisdictional boundaries can be better managed by agencies that have common goals, consistent approaches, and shared responsibilities. A larger population can be protected, resulting in a bigger gene pool.

- Utilizing opportunities for public education on conservation issues results in an increased feeling of community involvement; often misunderstanding and ignorance of the laws that apply to sensitive plant collection or disturbance can be resolved.

- Training of agency personnel in identification of sensitive plants and their habitat can more rapidly expand knowledge of plant distribution.

The following are Memoranda of Agreement (MOA) and cost-share funding ideas which will be investigated under this strategy. 

1) An MOA between clark county and BLM for the exchange of resource and land use information was jointly approved in 1981. Provisions to include the exchanged of GIS information will be proposed and implemented.

2) The transfer of sensitive plant information directly from the NNHP database to BLM's database will be investigated for feasibility. If this is not feasible, information will be transferred by hand.

3) Sensitive plant work shops will be designed and implemented. They will be developed at different intensity levels to accommodate participant's interests and needs. At the agency level, the workshops will focus on plant identification and inventory procedures.

4) Preliminary discussions have commenced on an interagency approach to the habitat management and recovery of the california bearclaw poppy (Arctomecon californicum), previously mentioned in section 2.1. This taxon is distributed on gypsum outcrops throughout BLM and NPS lands in Clark county. A multi-agency approach for conserving populations and critical habitat would involve BLM, NPS (Lake Mead Recreation Area), and TNC. Challenge cost-share funding sources for designing studies, management plans, and sharing management responsibilities will be investigated. The same procedure would be used for the potential re-introduction of Ute lady's tresses mentioned in section 2.1.2.1. The Las Vegas District will investigate challenge cost-share funding with TNC and FWS for research on plant propagation and seed germination studies for this orchid. Live material for re-introduction or research would have to be arranged with BLM in Utah, under whose jurisdiction natural populations still exist.

5) Attendance and participation in the bi-yearly Nevada sensitive plant workshops coordinated by the NNHP will be encouraged. In addition, the District will be involved with other state, regional, and national workshops that focus on SSP management.

6) Internship or Cooperative Education programs with UNLV which will provide assistance in BLM inventories and experience for the students will be investigated.

7) A Cooperative Agreement with the Nevada Division of Forestry to share information and facilities for propagating native plants (including SSP) for reintroduction and reclamation uses will be explored. 

In conclusion, the goals of this SSP strategy plan are dedicated toward habitat improvement and conservation of the Las Vegas District's sensitive plants. The objectives delineated in the plans can progress concurrently with one another, the end result being to make future listing of sensitive plants unnecessary.

\section{REFERENCES}

BLM. 1980a. Ash Meadows habitat management plan. N5-WHA-A1. BLM. Stateline-Esmerelda Resource Area. Las Vegas District, Las Vegas, NV.

BLM. 1980b. Caliente management framework plan. BLM State office, Reno, NV.

BLM, FWS, USFS, NV Dept.Nat.Res., NNHP, NNNPS, NV state Museum, TNC. 1991a. Endangered, threatened, and sensitive vascular plants of Nevada. JD Moorefield and TA Knight (eds.). BLM State office, Reno, NV.

BLM. 1991b. Conservation of rare plants and natural plant communities. Fish and Wildlife 2000. BLM, Washington, DC.

BLM. 1992a. Draft stateline resource management plan and environmental impact statement. Vol. I, II. BLM State office, Reno, NV.

BLM. 1992b. Draft southern Nevada desert tortoise habitat management plan. BLM, Las Vegas District office, Las Vegas, NV.

Schoolcraft, GD. 1990. Botanist's sensitive plant handbook. BLM, Susanville District, Susanville, CA.

Sada, DW. 1990. Recovery plan for the endangered and threatened species of Ash Meadows. USFWS, Portland, OR.

RECON. 1991. Short-term habitat conservation plan for the desert tortoise in Las Vegas Valley, Clark County, Nevada. Unpubl. Rept. for Clark County, Las Vegas, NV.

USFWS. 1992. Candidate species of Nevada. USFWS, Reno, NV. 



\section{APPENDIX 1. Sample of Nevada Natural Heritage form.}

MAIL TO: NEVADA NATURAL HERITAGE PROGRAM 123 W. Nye Lane, Room 168 , Carson City, NV 89710

OFFICE USE ONLY

PLEASE ENTER ALL INFORMATION AVAILABLE TO YOU. USE THE BACK FOR COMMENTS IF NECESSARY. PLEASE ATTACH OR ORAW A MAP ON BACK. Quad Code occurrence \#

Scientific name (no codes):

Reporter:

Phone: ( )

Address:

Date of Field Work: County: collection? If yes, \# Mus./ Location: $\overline{\text { day }} \overline{\text { mo. }}$ year

$T$ $f t(m) \quad T$
$1 \%$ of $1 \% \sec$ $7 / 21$ $15^{\prime}$ Elevation:
$1 /$. of $1 \% \operatorname{Sec}$
$R$

Landowner/Manager

Species found? Y__es No If not, reason:

Is this a new location record? Y__ Yes __ No Unknown

Total individuals = Is this a subsequent visit? Yes

Phenology (plants): \# vegetative

Population Age Structure (animals):

\# adul ts \# flowering breeding Herb

Site function for species (animals): wintering roosting denning \# others Habitat Description: (plant communities, dominants, associates, other rare spp., substrate/soils, aspect/slope)

Current Land Use/Visible Disturbances/Possible Threats

Overall site Quality: Excellent Good Fair Poor Corments:

Should/Could this site be protected? How?

Other Comments:

DETERMINATION (Check on or more, fill in blanks) Keyed in a site reference: Compared with specimen housed at: Compared with photo/drawing in: By another person (name): Other

OT $\overline{H E R}$ KNOWLEDGEABLE INDIVIDUALS (Name/Address/Phone)
PHOTOGRAPHS (check one or more)

Subject

Plant/Animal

Habitat

Diagnostic Feature

other

May we obtain duplicates at our cost? yes 
BLM Library

Denver Federal Center

Bldg. 50, OC -521

P.O. Box 25047

Denver, CO 80225 

